\title{
STUDY ON FINANCING CHANNELS OF SHIPPING COMPANIES IN CHINA
}

\author{
Yongmin Zhang ${ }^{1}$ and Xi Shen ${ }^{2}$ \\ ${ }^{I}$ Centre for Global Finance and Nottingham University Business School, University of Nottingham Ningbo China, China \\ ${ }^{2}$ Centre for Global Finance and International Finance Research Centre, University of Nottingham Ningbo China, China
}

\begin{abstract}
This paper studies financing channels in Chinese small and medium sized shipping companies and factors for the recent shipping market recession since 2008. Our data is based on a survey of opinions of more than one hundred top and middle level managers from shipping companies in Ningbo, which share typical characteristics of small and medium sized shipping companies in China. We develop two new influential scoring methods to analysing the data. The robustness test for our research findings are conducted by comparing the results from two methods.
\end{abstract}

Keywords:

Shipping Companies, Financing Channels, Influential Scoring

\section{INTRODUCTION}

\subsection{BACKGROUND}

Marine economy has attracted great attentions from both at home and abroad. In China, developing marine economy has become a key national strategy. It has been proposed in the twelfth five year plan (2011-2015) for Chinese national economic and social development. Moreover, in 2012, in the Eighteenth National Congress of the Communist Party of China, Chinese government developed strategic planning for marine economy. Furthermore, President $\mathrm{Xi}$ Jinping put forward the strategic conception of the "Silk Road Economic Belt" and "21st Century Maritime Silk Road" in 2013 also called "Belt and Road Initiatives". It is a development strategy and framework focuses on connectivity and cooperation among countries mainly in Eurasia but also include Oceania and East Africa. "Silk Road Economic Belt" includes countries in Central Asia, West Asia, the Middle East and Europe which situated on the original Silk Road but also extent to South Asia and Southeast Asia [2]. "21st Century Maritime Silk Road" covers the regions of Southeast Asia, Oceania and North Africa and includes the South China Sea, the South Pacific Ocean and the wilder India Ocean Areas. "The aim of the belt and road is to meet the development needs of China Countries along the routes and the region at large will serve the common interests of relevant parties and answer the call of the times for regional and global cooperation" [18]. To facilitate the implementation of strategic concept on the belt and road, in March, 2015, the Vision and Action Plan for "Silk Road Economic Belt" and "21st Century Maritime Silk Road" was jointly issued by National Development and Reform Commission (NDRC) of People's Republic of China, the Ministry of Foreign Affairs of People's Republic of China and the Ministry of Commerce of People's Republic of China. Chinese government has given a strong signal on marine economy. Therefore, marine economy is becoming a national strategic plan in China. More and more local policy makers, academics, investors and practitioners participate in the construction of marine economy in China.

Shipping industry is a traditional marine industry. It is also one of the key pillars of marine industry [11]. The new development in marine economy also brings opportunities and challenges for shipping industry. With the implementation of "Silk Road Economic Belt" and "21st Century Maritime Silk Road", shipping industry will benefit from increasing freight volume, cost saving and convenient facilities. It might also suffer fierce competition from other transportation methods such as railway and highway. Our earlier works [20,21] have provided suggestions on risk management, improving profitability and competitiveness of shipping companies in China. The purpose of this paper is to offer some recommendations on efficient financing strategies for shipping industry.

\subsection{IMPORTANCE OF SHIPPING INDUSTRY}

Shipping means the transport of cargo between seaports by ships [12]. Due to the different operation modes of ships, shipping industry can be divided in to two major sub sectors: liner shipping and tramp shipping. Shipping is a national strategic industry. It is also a cost-effective method which enables natural resources, raw materials, components, and goods to be transported over any long distance, compared with aviation, railway and road transportation. Mankind is highly depends on shipping to transport goods and foods around the world. There is around $80 \%$ of global trade by volume and over $70 \%$ by value fulfilled by sea [16]. Efthimios Mitropoulos, former IMO Secretary-General, remarked that "without the shipping industry, half of the world would freeze and the other half would starve".

\subsection{REASONS FOR CHOOSING NINGBO AS A CASE STUDY}

\subsubsection{Ningbo is an Important Port City in China:}

Ningbo has one of the biggest ports in the world [1]. Its container throughput ranked six in the world [16]. According to China port ranking list, Ningbo-Zhoushan port has already surpassed Shanghai port in terms of cargo handling capacity in 2012 and become China's top one port. Ningbo-Zhoushan port's total cargo volume reached 0.744 billion tons which was around 8 million tons more than Shanghai port [6]. As one of the most important port city in China, Ningbo will not only attract leading International shipping companies but also provide more opportunities for local shipping companies.

\subsubsection{Ningbo is the Core Area for the Development of Marine Economy in China:}

Zhejiang province has become the first National Marine Economy Development Zone since 2011 [10] which illustrates the importance of Zhejiang Province in the development of marine 
economy in China. Ningbo is a municipality with independent planning status in Zhejiang Province. In the Plan of Zhejiang Marine Economy Development Zone, Ningbo is the core area and plays a very important role in the development of marine economy [13]. Therefore, to some extent, the development of maritime economy in Ningbo represents Zhejiang province's marine economy development.

\subsubsection{The Characteristics of Shipping Industry in Ningbo:}

Although Ningbo has one of the biggest ports in the world, the development of shipping industry in Ningbo is relatively weak. According to Ningbo Ship and Port Administrative Bureau, there are around 140 shipping companies in Ningbo. Most of them are private owned and small-medium size. They are mainly serving for the domestic market, Yangtze River Delta in particular. There are only eight shipping companies (two of them are state owned i.e. Ningbo Marine Group Company Limited; Ningbo Ocean Shipping) participate in international market. Generally, Ningbo is strong in port but weak in shipping.

\subsection{FINANCING DEMAND OF SHIPPING COMPANIES}

Shipping industry is a capital intensive industry which requires a large amount of capital investment in ships [12]. Taking Panamax 75,000 dwt bulk ship for example, it costs around $\$ 29.5$ million in 2014 [8]. Shipping companies highly depend on external financing rather than internal funding. There is also evidence in our research that the debt to asset ratio is high in our sample companies (i.e. $32.6 \%$ of Ningbo shipping companies' debt to asset ratio is between $0-30 \% ; 28.4 \%$ of them is between $30-50 \% ; 23.2 \%$ of them is between $50-70 \%$ and $15 \%$ of Ningbo shipping companies' debt to asset ratio is over $70 \%$ ). In the meantime, shipping companies also have large expenditure on fuel. Fuel cost accounts for a great proportion of operation cost of shipping companies [7]. For example, according to Zhejiang Ocean Shipping, the fuel consumption for large bulk ship was around $\$ 30,000$ per day in 2012 [23]. In our research, we also include questions on purpose of financing of Ningbo shipping companies, the results show that the first purpose of financing is to buy ship and the second is for cash flow. That is to say, ship purchase and cash flow (mainly on fuel consumption) are two key financing demands in shipping companies.

\subsection{THE PURPOSE OF THIS RESEARCH}

This research is going to understand current financing channels and also the importance of different financing channels to shipping companies in Ningbo. Then, this paper will discuss some potential financing channels that can be adopted in order to provide insights on how to extend financing channels of shipping companies in Ningbo. Moreover, current market situation is an indispensable part of companies' decision and choice making. Therefore this paper will also explore the current situation of shipping companies in Ningbo and the main factors that lead to current situation. The following are the research questions:

- The current situation of shipping companies in Ningbo

- The major reasons or factors that influence current situation

- The current financing channels for shipping companies in Ningbo
- The importance of different financing channels

- Some new financing models

\section{METHODOLOGY}

We use survey method to collect data. The total number of questionnaires that we received is 109. The main participants include chairman of the board, CEO, general manager, manager, head of office, staff. There were three stages to collect data. At the first stage, the questionnaires were sent out to 140 shipping companies in Ningbo through mail with the help of Ningbo Shipping and Port Administration Bureau. However, the response rate is $14.3 \%$ (we only received 20 questionnaires). In the second and third stages, we sent out questionnaires while middle and top level managers attending training courses organized by Ningbo Marine Safety Administration.

In the questionnaire, most of the questions have multiple choices. The participants are required to order multiple choices for each question according to their importance. Then the results show that some answers are ordered while some answers are without order. That is to say, for the same question with multiple choices, some participants answer the questions and also order their choices. While some participants just choose the answers without ordering these choices. Therefore, two methods have been used to analyse the data.

In the first method, we do not consider the ordering of their choices. For each question, we simply count the number of participants who has selected a particular factor, which we define as the frequency of this factor. The Fig.1 displays frequencies of factors in decreasing order for the question of factors that lead to recession in shipping industry. For the second method, we consider the ordering of importance of choices. For each factor, it can be listed as the first choice by one person and listed in second or third choice by other participants. For each factor, we need consider the number of participants who place it as the first choice (frequency for the first choice), the number of participants who place it as the second choice (frequency fir the second choice), the number of participants who place it as the third choice (Frequency for the third choice), and so on. The Fig.2 displays frequencies by the order of choices for each factor. In order to compare importance of different factors, we can calculate the influential score for each factor using the following formula:

$$
\begin{gathered}
\text { Influential Score }=\sum_{i=1}^{n} \text { frequency }_{i} \cdot \text { weight }_{i}= \\
\text { frequency }_{1} \cdot \text { weight }_{1}+\text { frequency }_{2} \cdot \text { weight }_{2}+\text { frequency }_{3} \cdot \text { weight }_{3} \\
+\ldots+\text { frequency }_{n} \cdot \text { weight }_{n}
\end{gathered}
$$

where, frequency $y_{i}$ is the frequency for the $i^{\text {th }}$ choice, weight $i$ is the weight of the importance for the $i^{\text {th }}$ choice and $n$ is the total number of choices.

In this study, we define

$$
\text { weight }_{I}=n-i+1 \text {, }
$$

so that the first choice has weight $n$, the second choice has weight $n-1$, the third choice has $n-2, \ldots$, the $n^{\text {th }}$ choice has weight 1 , for example, if there are 9 choices, then the first choices has weight 9, the ninth choice has weight 1 . The Fig.1-3 displays influential scores for factors in decreasing order. 


\section{FINDINGS AND ANALYSIS}

Ninety nine answer their companies' financial performance in recent years. $43.4 \%$ think they still have a little profit, while $55.6 \%$ of them get losses. Among these $55.6 \%$ with losses, $20 \%$ suffers from serious loss in current shipping market. In general, shipping industry is in market downturn after 2008 financial crisis. There are many factors that lead to current situation. The participants have listed a few influential factors according to their understanding. As we have mentioned in the methodology part, two calculation methods have been adopted. The Fig. 1 is based on the first calculation (count the frequency of each factor without considering the order). The Fig. 2 is based on participants' order of the choices. The Fig. 3 is based the second calculation method.

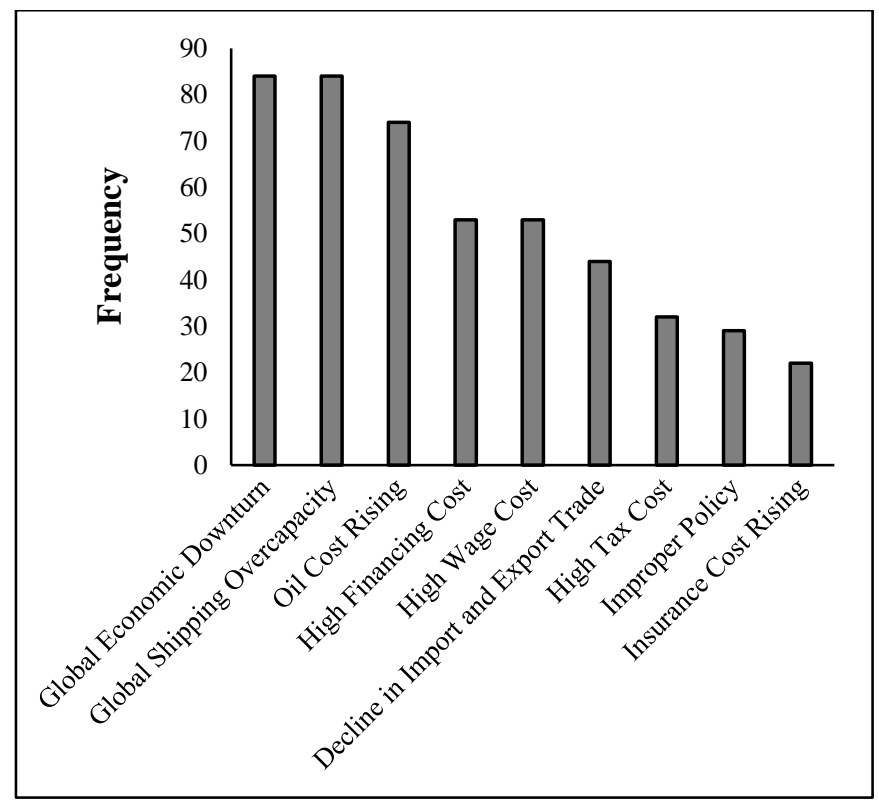

Fig.1. Factors that Lead to Recession in Shipping Industry (calculation method one)

From Fig.1 and Fig.3, it can be seen that global economic downturn, global shipping overcapacity and the rising cost of oil are the three key factors that lead to current depression in shipping industry. It is interesting that although we use two methods to calculate the results, the top three key factors are the same. Nevertheless, high financing cost listed as the fourth major reason for market depression based on method one. While it is the fifth major reason for market depression based on method two. In general, there is slight order difference for reasons like decline in import and export trade, high financing cost, high wage cost, improper policy, high tax cost and insurance cost rising.

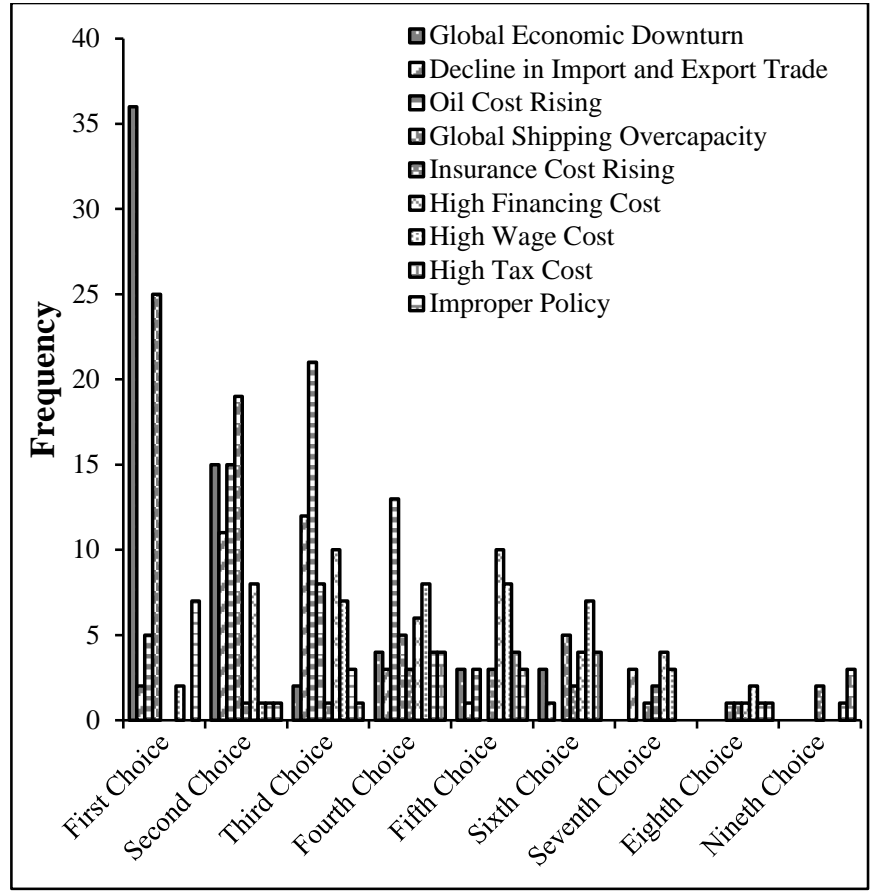

Fig.2. Factors that Lead to Recession in Shipping Industry (participants' initial order of the choices)

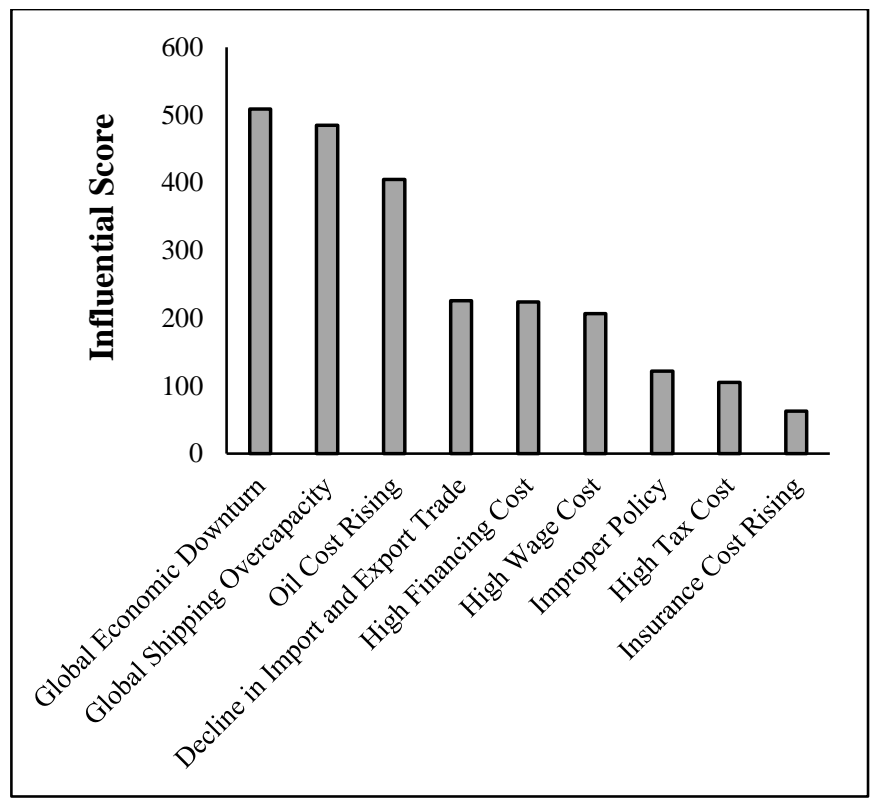

Fig.3. Factors that Lead to Recession in Shipping Industry (calculation method two)

Before financial crisis in 2008, shipping industry experienced a period of prosperity. A lot of shipping companies have invested in new ships to meet market demand. Normally it takes around 3 to 4 years for the construction of new ships. Then financial crisis arrived, the market demand declined dramatically but it cannot stop the delivery of new ships coming into the market. Therefore, just as most of participants' perception, global economic downturn and global shipping overcapacity are the key influential factors that lead to the current depression in the shipping market. In the meantime, crude oil price has increased rapidly in the last few years, so the proportion of fuel cost in total operation cost of 
shipping companies grows dramatically and some even exceed $60 \%$ [9]. Therefore, oil cost rising becomes a big pressure for shipping companies and is also perceived to be the third influential factor for current market depression. It is also worthy of noting that high financial cost is also one important issue that need to be concerned. Although in current shipping market, high financing cost seems not as influential as other factors. However, if the global economy and shipping market recover, the high cost of financing will become important to shipping companies. Apart from these factors listed by researchers, there are also other factors mentioned by a small number of participates, for example, unfair competition between state owned and private enterprises; high repair and material fee; low freight rate; chaotic cargo argent market; the price control by a small number of agents; high and various port management fee.

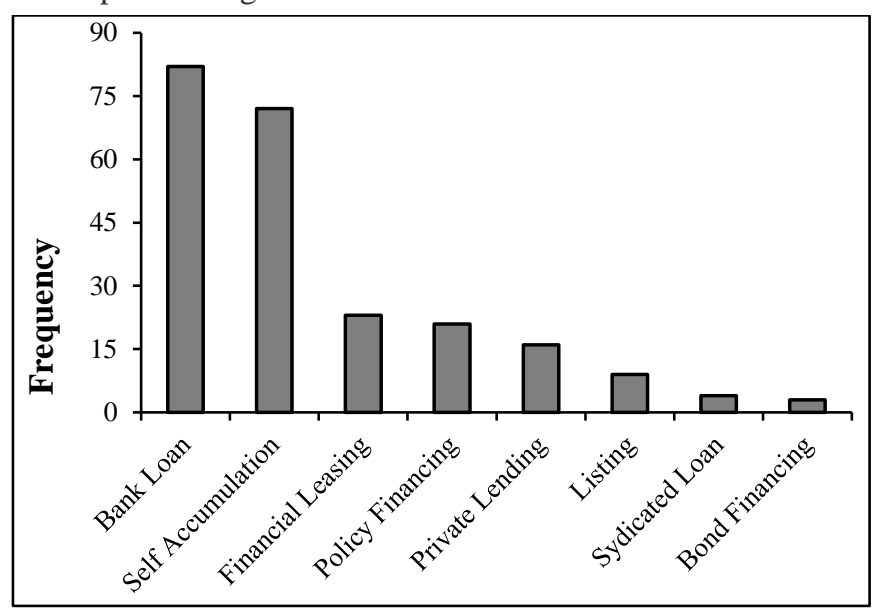

Fig.4. Major Financing Channels for Ningbo Shipping Companies (calculation method one)

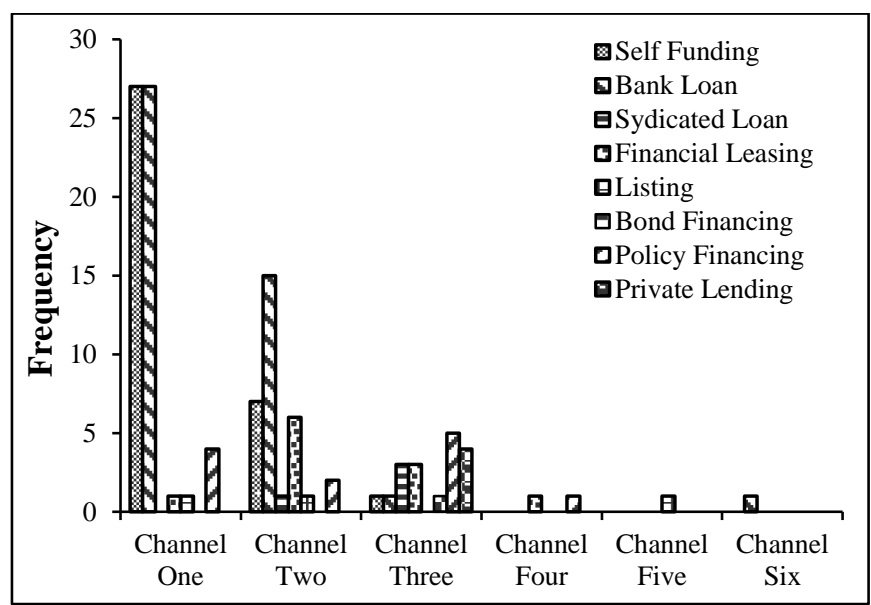

Fig.5. Major Financing Channels for Ningbo Shipping Companies (participants' initial order of the choices)

Under current market situation, the major financing channels for shipping companies are demonstrated in Fig.4, Fig.5 and Fig.6. Both of the two calculation methods reveal that bank loan is the first financing channel of Ningbo shipping companies like most Chinese industries. Company's self-funding is the second financing channel. Nevertheless, based on the first calculation method, financial leasing is the third financing method for Ningbo shipping companies and policy financing is the fourth channel.
While the second calculation method shown that policy financing is the third most used financing channel and financial leasing is the fourth channel for Ningbo shipping companies' financing. It is worthy of noting that syndicated loan is not a very popular financing channel. It is listed in the seventh place based on the first calculation method and in the fifth place based on the second calculation method. However, syndicated loan is the most popular financing channel in the international shipping market. That is because the total bank loan of shipping industry exceeds 500 billion USD. Single bank has limited capability and ability to undertake large load with huge risk. Therefore, banks cooperate with each other to share risks [19]. To some extent, the less popularity of syndicated loan among Ningbo shipping companies represents that shipping companies' size in Ningbo are small and medium and their financing demand is not so huge. In the meantime, listing and bond financing are also not very popular financing channels.

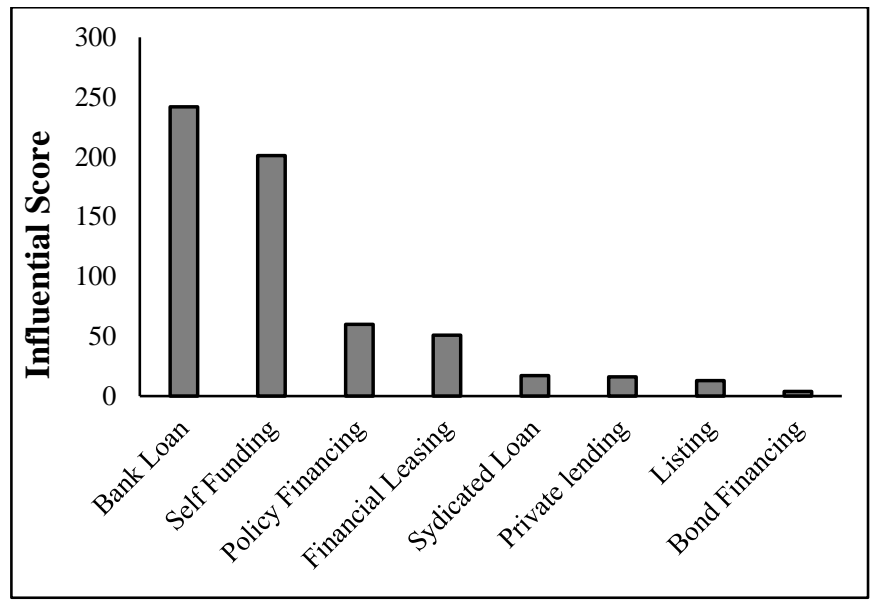

Fig.6. Major Financing Channels for Ningbo Shipping (calculation method two)

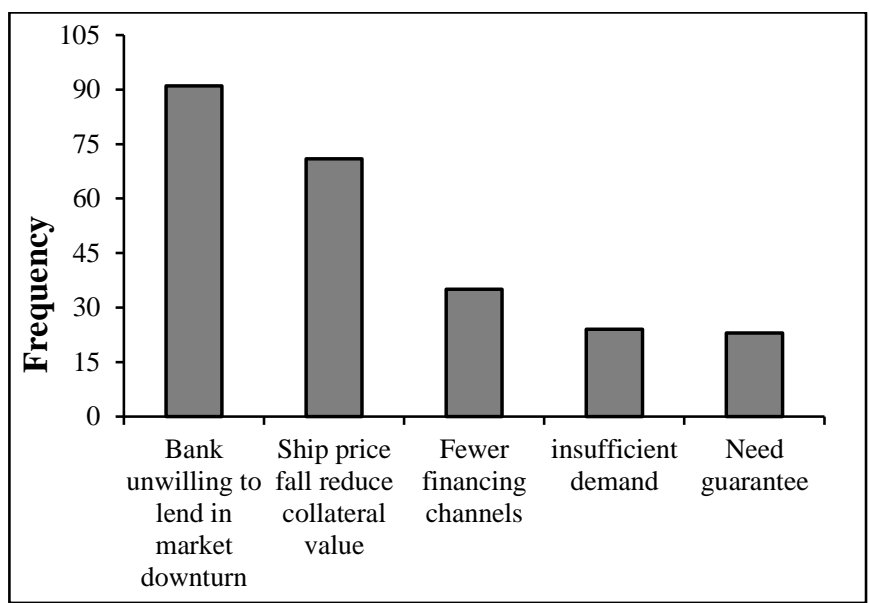

Fig.7. Reasons for Financing Difficulties (calculation method one)

Ningbo shipping companies suffer from money shortage in current market depression. Some of them even go to bankruptcy. Because of narrow financing channels, companies highly rely on banks for financing. However, under current market depression, banks as the major financing channel are unwilling to provide financing service to shipping companies. In Chinese banking 
system, company need collateral to get loan. Normally, ships will become collaterals. However, ship price goes down dramatically because of insufficient demand and serious problem of overcapacity in shipping industry. Ship's collateral value as a pledge also decreases rapidly. So banks are unwilling to lend money to shipping companies. The Fig.7, Fig.8 and Fig.9 show the reasons of financing difficulties perceived by Ningbo shipping companies.

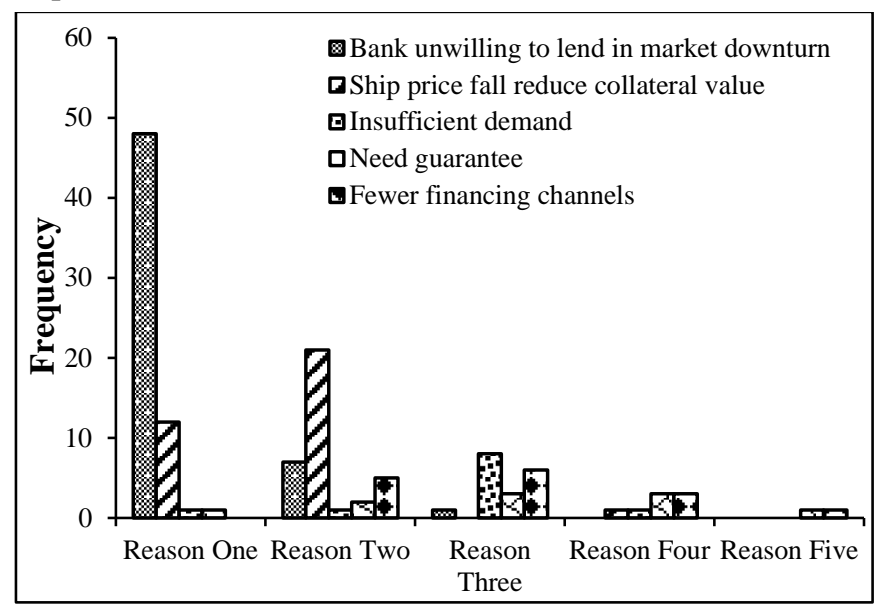

Fig.8. Reasons for Financing Difficulties (participants' initial order of the choices)

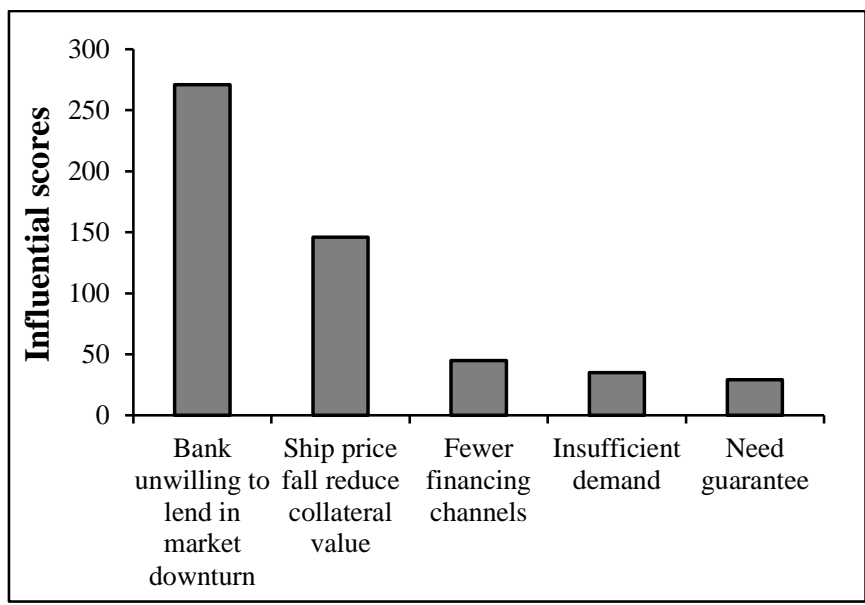

Fig.9. Reasons for Financing Difficulties (calculation method two)

Although the current financing channels for Ningbo shipping companies are quite narrow, they still expect more channels to be available and their perception on the importance of various financing channels are demonstrated in Fig.10 and Fig.11. As different participates have different perception, in order to provide a clear view on the importance of various financing channels. We give weight to each choice (very important 5 , important 4 , Neutral 3 , unimportant 2 , and very unimportant 1 ). The total score for each financing channel is the weight sum for frequencies.

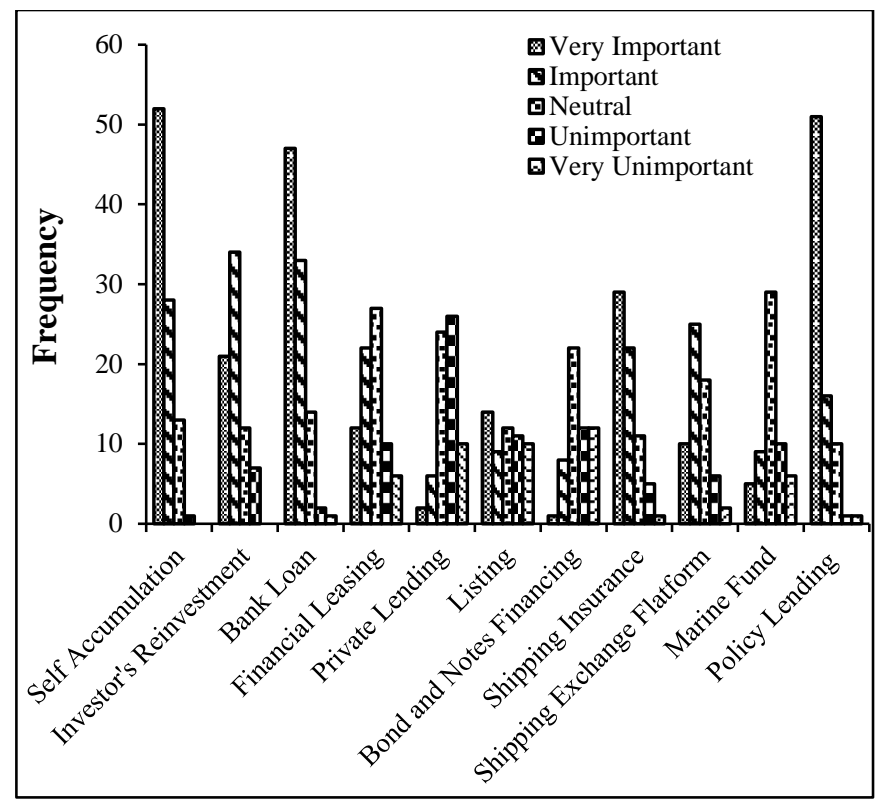

Fig.10. Importance of Various Financing Channels Perceived by Ningbo Shipping Companies (participants' initial order of the choices)

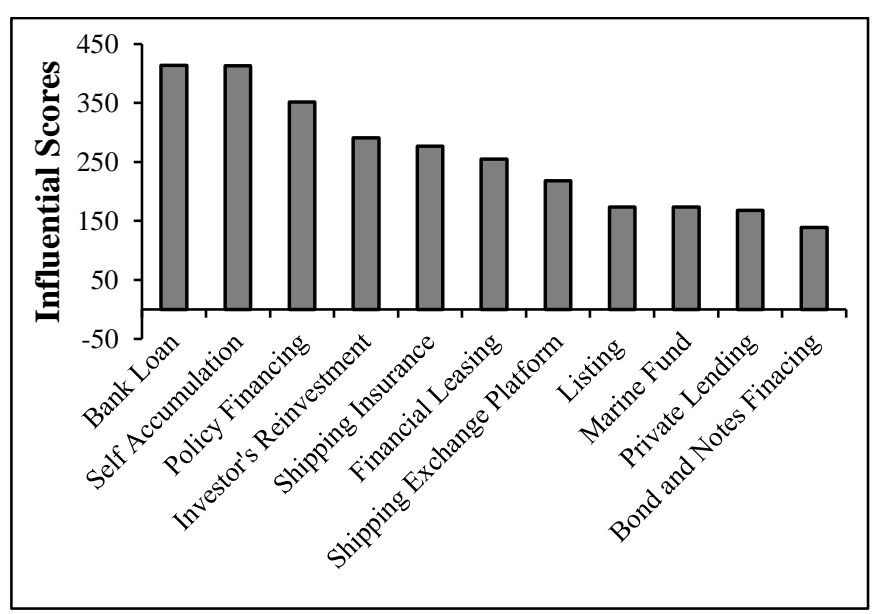

Fig.11. Importance of Various Financing Channels Perceived by Ningbo Shipping Companies (weight 5 to 1 was given to each choice from very important to very unimportant)

From Fig11, it can be seen that bank loan is perceived to be the most important financial channel followed by self-funding. It is interesting to see that bank loan and self- funding which are perceived as the two most important channels by managers (Fig.11) are also the most popular existing financing channels used by shipping companies (Fig.4, Fig.5). Meanwhile, listing, private leading as well as bond and note financing are the least important channels for them. Company's investors' reinvestment is also important channel to get financing. Marine Industry Fund is not playing an important role according to Ningbo shipping companies In 2011, Ningbo established the first national Marine Industry Fund. The target capital scale is RMB10 billion (equal to USD 1.64 billion). It is a government led fund and will invest in innovative, high growth potential and technical marine companies. The size of company is not the major concern of the Ningbo Marine Industry Fund. Therefore, Marine Industry Fund as a financial innovation 
product still at its development stage, it takes time to become an important financing channel for Ningbo shipping companies.

\section{NEW FINANCING MODELS}

In general, there are around 140 shipping companies in Ningbo. Most of them are small and medium sized company. They are mainly doing business in national costal area, Yantze River delta in particular. Their core business is dry bulk shipping. Most of Ningbo shipping companies are losing money. Some even go to bankruptcy. They like most companies in the shipping industry are suffering from global market downturn and seriously global shipping overcapacity. Meanwhile, they are also influenced by the increase of oil price which is also one of the key factors that lead to shipping market depression. Although in the time of writing, the oil price goes down a little bit, the volatility of oil price plays a very important role in shipping companies. That is because the cost of fuel takes a great percentage of company's total operation cost.

Ningbo shipping companies heavily rely on bank to get financing. However, banks are unwilling to lend money to shipping companies. That is because business model of bank is that companies must have pledge to guarantee their loan. Ship usually plays the role of pledge. However, in market downturn, the value of ship shrinks dramatically. There is also potential risk for bank as the price of ship might go down further. Therefore, it is very hard for shipping companies to get loan from banks in current market situation. Nevertheless, bank is key financing channel for shipping companies in Ningbo. So under current financing model and current market depression, Ningbo shipping companies face difficulties in financing. This will impede the healthy development of shipping industry which plays a very important role in marine economy and the construction of "Silk Road Economic Belt" and "21st Century Maritime Silk Road". Therefore, it is urgent to extend shipping companies' financing channels and improve their overall competitiveness. The following are some suggestions on how to extend shipping companies' financing channels.

Firstly, learn from world advanced financing leasing (equipment leasing) models and apply them to Ningbo shipping industry with the consideration of local demands and characteristics. In global shipping financing market, financing leasing is the second financing channel of shipping companies. The first financing channel is bank. The scale of financing leasing achieves USD 70 billion which is $1 / 4$ of bank loan. There are many financing leasing models in the world such as Germany $\mathrm{KG}$ (Kommanditgesellschaft) fund [15], UK tax leasing and Norwegian KS system. The most influential one is Germany KG (Kommanditgesellschaft) fund [17] [3], a traditional and typical way of ship financing originated in Germany that attracts private investors by offering a tax efficient structure with each fund typically owning one ship [14]. The operation model of $\mathrm{KG}$ Shipping Fund is like following: equity house set up a KG shipping fund to buy ships. The money partly comes from private investors $(35 \%-50 \%)$ and partly from bank $(50 \%-65 \%)$. Bank get prime mortgage of the ship. Then shipping company rent ships from $\mathrm{KG}$ shipping fund. The benefits of KG shipping fund are that shipping companies don't need to invest much money in ship purchase. They only need to pay for rent to KG shipping fund and get the right to use. In the meantime, KG shipping fund financing cost will not be included in shipping company's balance sheet which will reduce their debt ratio and optimize their financial reports. Moreover, private investors can benefit from government subsidiary and tax reduction. Furthermore, banks can reduce their risk in lending. Although after financial crisis in 2008, KG shipping fund also suffer from great lose and the percentage of bank invest in $\mathrm{KG}$ fund is decreasing, it is still a good financing model. Ningbo is rich in private capital. With government support in terms of preferential policies and tax reduction, $\mathrm{KG}$ shipping fund model will become an influential financing channel for Ningbo shipping companies (see detail for the operation model of KG Shipping Fund).
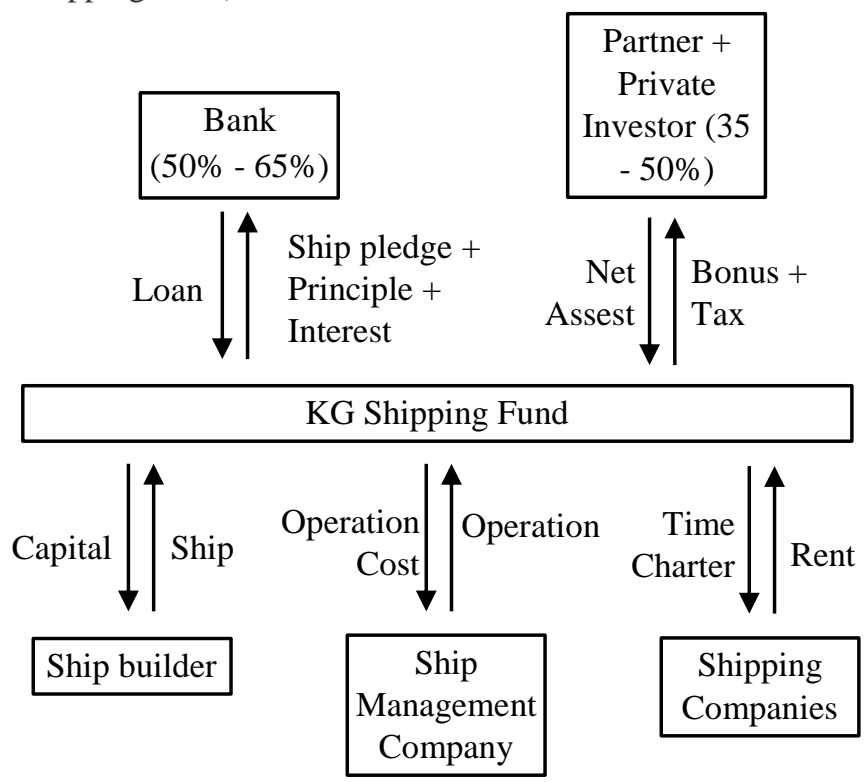

Fig.12. Germany KG Shipping Fund

Secondly, fully use Ningbo Marine Industry Fund in shipping financing and also develop shipping industry funds. Marine Industry Fund was set up in 2011. Ningbo Development and Investment Group Co. Ltd. Shanghai Marine Industry Fund Management Co. Ltd. Ningbo National Hi-tech Zone Development and Investment Corporation are the investors. The initial investment is RMB 0.5 billion (equal to USD 82 million) and their investment ration is 4:4:2. Marine Industry Fund's initial plan for fund raising is RMB 3 billion (equal to USD 0.49 billion) from private enterprises, financial institutions and investors. The fund plans to achieve RMB 10 billion (equal to USD1.64 billion) in total. However, in so far few reports or news are released about the status of the fund. And also according to the participants of our research, Marine Industry Fund has yet to play an important role in financing Ningbo shipping companies. Therefore, to solve financing difficulties and extend financing channels of Ningbo shipping companies, there are bigger roles for Marine Fund and Shipping Fund to play. Government are initiator for these types of funds. They are yet to get more support from financial institutions who can effectively manage these funds market.

Thirdly, explore internet financing model to extent Ningbo shipping companies' financing channel. In recent years, with the deficiencies of traditional financing products and the strong market demand, internet financing is flourishing in China. It even appeared in Chinese government work report in 2014 [4]. There are also broad development prospects in shipping industry and internet financing. Ningbo has already established shipping exchange 
platform in 2011. The internet financing can based on this platform and connect the investment and financing demand of investors and Ningbo shipping companies. Nevertheless, there are huge risks in internet financing, so professional risk management knowledge, technology and skills are required for Ningbo government, financial institutions, investors and Ningbo shipping companies.

\section{CONCLUSIONS}

In this paper, we have presented a survey study for shipping companies in Ningbo, which share typical characteristics of small and medium sized shipping companies in China We developed two factor influential scoring methods to analyse the survey data, which is based on opinions of more than hundred top and middle level managers in Ningbo shipping companies.

We find global economic downturn, global shipping overcapacity and oil cost rising are the top three reasons for leading the shipping industry in recession. We also find bank loan and self-funding are the two major existing financing channels for shipping companies in Ningbo. Managers also think that these two financing models together with policy financing are still most important channels to date. Because the relative small size of shipping companies in Ningbo, offer financing methods which are popular for large international shipping companies such as syndicated loan and bond financing for accessing larger funding are not common.

The survey also find the major reasons for financing difficulties facing by Ningbo shipping companies are the unwillingness of banks to lend in market downturn and the fall of shipping price which reduces values of collaterals. To solve these difficulties, we discuss several new financing models: $\mathrm{KG}$ shipping fund, investment fund for marine industry and internet finance.

\section{ACKNOWLEDGEMENT}

This research is supported by Ningbo-CASS Strategic Cooperative Fund.

\section{REFERENCES}

[1] American Association of Port Authorities, Available at: http://www.aapaports.org/unifying/content.aspx? ItemNumber $=21048$

[2] Caixin, "One Belt, One Road", Available at: http://english.caixin.com/2014-12-10/100761304.html, Accessed on 2014.

[3] Pierre Cariou and Francois-Charles Wolff, "Chartering Practices in Liner Shipping", Maritime Policy and Management, Vol. 40, No. 4, pp. 323-338, 2013.

[4] China Daily, "Internet Financing Boom", Available at: http://www.chinadaily.com.cn/business/2014-

04/10/content_17424013.htm, Accessed on 2014.

[5] Liu Cigui, "Reflections on Maritime Partnership: Building the 21st Century Maritime Silk Road", Available at: http://www.ciis.org.cn/english/201409/15/content_7231376.htm

[6] Chinese Port, Available at: http://info.bfb56.com/news/54297.html, Accessed on 2013.
[7] T.E. Notteboom and B. Vernimmen, "The Effect of High Fuel Costs on Linner Service Configuration in Container Shipping", Journal of Transport Geography, Vol. 17, No. 5, pp. 325-337, 2009.

[8] Drewry Maritime Research, Available at: https://www.marinelink.com/news/maritime/drewrymaritime-research, Accessed on 2014.

[9] Mihalis M Golias, Georgios K Saharidis, Maria Boile, Sotirios Theofanis and Marianthi G Ierapetritou, "The Berth Allocation Problem: Optimizing Vessel Arrival Time", Maritime Economics and Logistics, Vol. 11, No. 4, pp. 358377, 2009.

[10] The Central People's Government of the People's Republic of China, Available at: http://www.gov.cn/jrzg/201103/02/content_1814630.htm.

[11] International Maritime Organization, "Maritime Knowledge Centre (MKC)", Available at: http://www.imo.org/en/KnowledgeCentre/Pages/Default.as px.

[12] Yuen Ha Lun and Kee Hung Lai and T.C.E. Cheng, "Shipping and Logistics Management", $1^{\text {st }}$ Edition, Springer, 2010.

[13] National Development and Reform Commission, Available at: http://en.ndrc.gov.cn/newsrelease/201503/t20150330_6693 67.html.

[14] Ross and Odell, "European Banks Face Tough 2014 as ECB Focuses on Shipping", Available at: http://www.ft.com/intl/cms/s/0/aa034d9a-6bf1-11e3-a21600144feabdc0.html\#axzz3ga8AljNy

[15] Martin Stopford, "Maritime Economics", $3^{\text {rd }}$ Edition, Routledge, 1988.

[16] "Review of Maritime Transport", Available at: http://unctad.org/en/PublicationsLibrary/rmt2012_en.pdf

[17] C. Von Oldershausen, "German KG Financing, 3 Well Proven Ship Finance Alternative: Overview and Future Challenge", Proceedings of Fourth City of London Biennial Meeting, Vol. 6, No. 7, pp. 1-6, 2005.

[18] Xi Jinping, "Xi on "Belt and Road": Not China's solo but inspiring chorus", Available at: http://news.xinhuanet.com/english/201503/28/c_134105208.htm

[19] Yongming Zhang, Xiuaogang Bi, Conghua Wen, Xi Shen, Shusheng Ding and Wenjun Tu, "Marine Economy and Its Investment and Financing Strategy", China Financial Publishing House, 2015.

[20] Yongmin Zhang and Xi Shen, "Suggestions for Improving Profitability and Competitiveness of Shipping Companies in China", ICTACT Journal on Management Studies, Vol. 2, No. 2, pp. 312-321, 2016.

[21] Yongmin Zhang and Xi Shen, "The Strategies for Market Risk Management in International Shipping", Management Studies, Vol. 2, No. 7, pp. 447-464, 2014.

[22] Yongmin Zhang and Xi Shen, "Studies on Market Risk Management Strategies in Shipping Companies", World Shipping, Vol. 37, No. 233, pp. 6-11, 2014.

[23] Zosco, "Keep on Doing Ship's Energy Saving”, Available at http://www.zosco.com/news_detail.asp?fid=326, Accessed on 2012. 